\title{
The Battle Between Politics and Science Is Costing Us a Timely Victory Over the COVID-19 Pandemic
}

Marc B. Hahn, DO

From Kansas City University in Kansas City, Missouri.

Financial disclosures:

None reported.

Support: None reported.

Address correspondence to

Marc B. Hahn, DO,

1750 Independence Avenue,

Kansas City, MO 64106.

Email: president@kansascity.

edu

Submitted

August 27, 2020;

revision received

September 11, 2020;

accepted

September 21, 2020.

\section{Against the backdrop of the COVID-19 pandemic, the author discusses what} he views as a persistent tension between the nature and aims of politics vs science. He outlines a call to action for osteopathic physicians to stand with science, advocate for best practices, undertake dialogue with local and state health authorities, and act as role models for colleagues and patients alike.

J Am Osteopath Assoc. 2020;120(11):806-807. Published online October 7, 2020.

doi:10.7556/jaoa.2020.141

Keywords: coronavirus, COVID-19, politics, science

he fact that the United States (US) leads the world by a significant margin in both novel coronavirus disease 2019 (COVID-19) cases and deaths, ${ }^{1}$ with no clear solution looming on the horizon to bring either in check, is a tragedy that should shock us all- but it shouldn't surprise us.

Underlying the pandemic's grip on our nation is a fierce yet familiar tug-of-war between the rigid and entrenched tenets of politics on one side with the flexible and fluid nature of science on the other. Science and politics have long been squarely at odds. ${ }^{2}$ However, the current environment regarding mask-wearing, ${ }^{3}$ social distancing, ${ }^{4}$ advocacy for untested treatments, ${ }^{5}$ and vaccine development ${ }^{6}$ allows the impact of these opposing forces to play out on a scale of epic proportions, impeding science and progress with grave implications during the most challenging public health crisis in our nation's history. ${ }^{7}$

Politics inherently pledges allegiance to ideologies, interests, and agendas fomented by strident partisanship. Politics relies on selective analysis, weaving into its narratives only those facts that ignite passion, support certain truths, or are deemed necessary to bolster specific conclusions or justify desired positions. ${ }^{8}$ Political beliefs seek to reinforce what each group's adherents knows, understands, and values on the deepest emotional levels. As a result, political beliefs and behaviors generally can't or won't change, and those who embrace them rarely admit to being wrong, no matter the cost. ${ }^{9}$

Conversely, science insists on questioning belief systems and is open to new and potentially differing conclusions. It considers varying opinions that change depending upon available information and the progression of knowledge. True science relies on embracing all facts, combining and considering them collectively over time. Good science has passion but no particular point of view. Rather, it will evolve as new knowledge emerges. ${ }^{10}$

We continue to see what happens when we ignore the facts of science and put partisan issues ahead of public health. The US is now suffering from a crushing resurgence of the coronavirus with the daily number of COVID-19 new cases and deaths escalating across the country. ${ }^{11}$ Fighting a pandemic is one of the greatest challenges we will face as a society; attempting to do so through a political lens makes it nearly impossible. The 
very nature of politics (whether liberal or conservative) renders it unfit to ever truly protect or maintain the public health. Our country must insist on transparent, science-based responses led by public health experts who are undeterred by political interests.

Currently, partisan politics is dominating our response to COVID-19. Our country has regressed, with the dark prospect of an even more staggering loss of life and a severe hobbling of our economy; indeed, the US economy is likely to lag those of other developed countries for much of the foreseeable future. A September forecast from the Centers for Disease Control and Prevention estimates as many as 226,000 total COVID-19 deaths by October $17 .^{12}$ The US Bureau of Labor Statistics reported that 13.6 million US citizens were out of work as of August 2020, up 7.8 million since February. ${ }^{13}$ It did not have to be this way.

Although scientific facts drove early shutdowns with promising results, ${ }^{14}$ we let our guard down too soon. ${ }^{15}$ We stopped listening; impatience and selfishness supplanted science. We had the facts, but chose to disregard them.

Politics (with its selective analysis of data) and science (with its ever-changing meta-analysis) will likely forever remain at odds. When it comes to fighting a major public health crisis on the magnitude of the current global COVID-19 pandemic, the only answer is for politics to yield to science. As osteopathic physicians, we must always stand with science in its constant struggle with various political agendas. In doing so, we can serve as role models for our colleagues, advocates for best practices with our elected officials, resources for our local and state health authorities, and sources of trusted health information for our patients and communities.

\section{References}

1. Johns Hopkins University and Medicine Coronavirus Resource Center. Accessed September 24, 2020. https://coronavirus.jhu.edu/map.html
2. Branscomb LM. Science, politics, and U.S. democracy. Issues in Science and Technology. Accessed September 24, 2020. https:// issues.org/branscomb-3

3. Witte G, Cha EA, Dawsey J. At the heart of dismal U.S. coronavirus response, a fraught relationship with masks. Washington Post. Published July 28, 2020. Accessed September 24, 2020. https://www. washingtonpost.com/national/at-the-heart-of-dismal-us-coronavirusresponse-a-fraught-relationship-with-masks/2020/07/28/f47eccd0cde4-11ea-bc6a-6841b28d9093_story.html

4. Clinton J, Cohen J, Lapinski, JS, Trussler M. Partisan pandemic: how partisanship and public health concerns affect individuals' social distancing during COVID-19. Published July 9, 2020. Accessed September 24, 2020. https://ssrn.com/abstract=3633934

5. Grady D, Kannapell A. Trump urges coronavirus patients to take unproven drug. The New York Times. Published April 4, 2020. Accessed September 24, 2020. https://www.nytimes.com/2020/04/04/ health/coronavirus-drug-trump-hydroxycholoroquine.html.

6. LaFraniere S, Thomas K, Weiland N, Baker P, Karni A. Scientists worry about political influence over coronavirus vaccine project. The New York Times. Published September 1, 2020. Accessed September 24, 2020. https://www.nytimes.com/2020/08/02/us/politics/ coronavirus-vaccine.html

7. Fidler DP. Vaccine nationalism's politics. Science. 2020;369 (6505):749. doi:10.1126/science.abe2275

8. Van Bavel JJ, Pereira, A. The partisan brain: an identity-based model of political belief. Trends in Cognitive Sciences. Published February 20, 2018. Accessed September 24, 2020. doi: 10.1016/j.tics.2018.01.004

9. Pew Research Center, U.S. Politics \& Policy. Political polarization in the American public. Published June 12, 2014. Accessed September 24, 2020. https://www.pewresearch.org/politics/2014/06/12/ political-polarization-in-the-american-public/

10. Stacpoole PW, Fisher WR, Flotte TR, Geiser EA, Theriaque DW, Hutson $A D$. Teaching hypothesis-oriented thinking to medical students: the university of Florida's clinical investigation program. Acad Med. 2001;76(3):287-92. doi:10.1097/00001888-200103000-00022

11. United States COVID-19 Cases and Deaths by State. Centers for Disease Control and Prevention website. Accessed September 24, 2020. https://www.cdc.gov/coronavirus/2019-ncov/cases-updates/ cases-in-us.html

12. Forecasts of COVID-19 Deaths. Centers for Disease Control and Prevention website. Accessed September 24, 2020. https://www.cdc. gov/coronavirus/2019-ncov/covid-data/forecasting-us.html

13. Employment Situation Summary. U.S. Bureau of Labor Statistics. Accessed September 24, 2020. https://www.bls.gov/news.release/ empsit.nro.htm

14. Hsiang S, Allen D, Annan-Phan S. et al. The effect of large-scale anti-contagion policies on the COVID-19 pandemic. Nature. 2020;584: 262-267. doi: 10.1038/s41586-020-2404-8

15. Information is beautiful. Accessed September 24, 2020. https:// informationisbeautiful.net/visualizations/covid-19-coronavirusinfographic-datapack/

๑) 2020 American Osteopathic Association 